УДК 378.14:379.8

DOI:

Тетяна Логвиненко, доктор педагогічних наук, професор завідувач кафедри соціальної педагогіки та корекиійної освіти Дрогобицького державного педагогічного університету імені Івана Франка Мар'яна Клим, кандидат педагогічних наук, дочент кафедри соиіальної педагогіки та корекиійної освіти Дрогобицького державного педагогічного університету імені Івана Франка

\title{
ПРОФЕСІЙНА ГОТОВНІСТЬ МАЙБУТНІХ СОЦІАЛЬНИХ ПЕДАГОГІВ ДО РОБОТИ В ІНКЛЮЗИВНОМУ СЕРЕДОВИЩІ
}

У статті проаналізовано особливості професійної готовності майбутніх сочіальних педагогів до роботи в інклюзивному середовищі. Професійна готовність майбутніх фахівців соціальної сфери у ичьому контексті визначається як спеціально організований циілісний системний процес педагогічної діяльності закладу вищої освіти, щзо має на меті формування у майбутніх соиіальних педагогів високої компетентності й готовності до виконання професійних функиій у соичіальній та соціально-педагогічній роботі відповідно до потреб і особливостей розвитку суспільства.

Центральними суб' сктами професійної підготовки майбутніх соціальних педагогів виступають викладач і студент, де професійна педагогічна діяльність тісно взаємодіє з навчальною діяльністю студента, які будуються на спільному прагненні досягнути високого результату у підготовці фахівців до майбутньої діяльності. Завдяки реалізації тренінгових технологій у системі підготовки майбутніх соціальних педагогів відбувається формування цінностей, вмінь, навичок життєвих та фахових компетентностей, студенти мають можливість усвідомити негативні прояви різних сочіально-корекційних ситуацій на особистісному рівні, важливість попередження чи подолання різного виду асочіальних проявів у майбутній професійній діяльності.

Ключові слова: професійна готовність; майбутні сочіальні педагоги; інклюзивне середовище; тренінгові технологї; професійна діяльність.

תim. 11.

Tetyana Lohvynenko, Doctor of Sciences (Pedagogy), Professor, Head of the Social Pedagogy and Correctional Education Department Drohobych Ivan Franko State Pedagogical University Maryana Klym, Ph.D. (Pedagogy), Associate Professor of the Social Pedagogy and Correctional Education Department Drohobych Ivan Franko State Pedagogical University

\section{PROFESSIONAL READYNESS OF FUTURE SOCIAL PEDAGOGUES TO WORK IN AN INCLUSIVE ENVIRONMENT}

The article deals with the features of professional readiness of future social pedagogues to work in an inclusive environment. Professional readiness of future social pedagogues is defined in this context as a specially organized holistic systemic process of pedagogical activity of higher education institution. It aims to form in future social pedagogues high competence and readiness to perform professional functions in social and socio-pedagogical work according to needs and features of society development.

The central subjects of professional training of future social pedagogues are the teacher and the student, where professional pedagogical activity closely interacts with the student's educational activity. It is based on a common desire to achieve a high result in training the professionals for future activities. It is established that the professional readiness of social pedagogues to carry out activities in an inclusive environment in recent years has become relevant as a theoretical problem and as a real practical activity. It is in response to the dynamic social processes that have embraced the modern political, social and economic space of many countries and increases the need to improve the education of children with special educational needs, their well-being for creating better conditions for their rights. Due to the implementation of training technologies in the system of training future social pedagogues is the formation of values, skills, life and professional competencies, students have the opportunity to understand the negative manifestations of various social and corrective situations at the personal level, to understand the importance of preventing or overcoming various antisocial manifestations.

Keywords: professional readiness; future social pedagogues; inclusive environment; training technologies; professional activity.

П остановка проблеми. Розглядаючи освіту крізь призму інклюзії, необхідно відзначити зміну уявлення про цінності кожної дитини з особливими освітніми потребами і необхідності перегляду стандартів системи освіти. У сучасних умовах розвитку наша держава активно рухається до втілення ідей інклюзивної освіти, хоча заклади загальної 


\section{ПРОФЕСІЙНА ГОТОВНІСТЬ МАЙБУТНІХ СОЦІАЛЬНИХПЕДАГОГІВ ДОРОБОТИ В ІНКЛЮЗИВНОМУ СЕРЕДОВИЩІ}

середньої освіти в своїй більшості не мають достатніх умов та ресурсів для реалізації даного процесу (відсутність належної методичної, матеріальної та кадрової бази).

Для сучасного соціального педагога інклюзія має змістовно-конструктивні бар'єри, що вимагають сформованості певних компетенцій. Саме тому, актуальною є проблема вивчення i оптимізації професійно-особистісної готовності соціальних педагогів, підвищення соціальнопедагогічної компетентності, мобільності соціального педагога, що працює в умовах впровадження інклюзивної освіти $[1,38 ; 4,370]$.

Актуальність розгляду даної проблеми визначається тим, що використання корекційних технологій, інновації в освітньому процесі, якість взаємодії з суб'єктами освіти стають, з одного боку, показником рівня компетентності майбутнього соціального педагога, його професійно-особистісної готовності, а іншого дієвим засобом реалізації інклюзії, одним 3 найбільш ефективних умов її вдосконалення. Цей складний процес вимагає організаційних, змістових і ціннісних змін.

Аналіз останніх публікацій та досліджень. Аналіз психолого-педагогічної та методичної літератури засвідчує, що різноманітні аспекти готовності майбутніх соціальних педагогів до здійснення професійної діяльності досліджують Н. Васягіна [2], І. Зязюн [3], Н. Марчук [2], Л. Міщик [7], С. Харченко [10] та ін.

Професійну підготовку науковці розглядають як полісемічний термін, який означає одержання кваліфікації або спеціальності, спеціально організований процес, фахову готовність до виконання майбутніх завдань. Компоненти, що входять до професійно-особистісної готовності, обгрунтовують як інтегративний конструкт особистості, професійну активність і життєдіяльність суб'єкта, утвореного системою смислових відносин, цінностей, установок, мотивацій і Я-концепції, що відображає специфіку професійної діяльності.

Тенденції розвитку професійно-особистісної готовності майбутніх соціальних педагогів до роботи в інклюзивному середовищі В. Бондар [1], I. Івенських [2], Т. Ілляшенко [5], А. Колупаєва [6], С. Сорокоумова [9] частково аналізують. Дослідники зазначають, що зміст професійної, соціально-педагогічної підготовки є динамічним системним утворенням, обсяг і глибина якого в основному визначаються інформаційними потребами майбутнього соціального педагога. Однак, як свідчить аналіз наукових джерел, проблема організації та професійної готовності майбутнього соціального педагога до здійснення діяльності в інклюзивному середовищі залишається ще недостатньо вивченою.

Мета статті - проаналізувати специфіку формування професійної готовності майбутніх соціальних педагогів до роботи в інклюзивному середовищі.

Виклад основного матеріалу. Модернізація освіти задає нові орієнтири до підготовки фахівців для системи загальної середньої освіти, що працюють в умовах інклюзивної практики. Соціально-педагогічний супровід в умовах інклюзії повинен починатися якомога раніше і проходити з урахуванням сенситивних періодів розвитку дітей 3 особливими освітніми потребами, з урахуванням якісних вікових психічних новоутворень через організацію провідних видів дитячої діяльності. Діагностична, корекційна і розвиваюча робота повинна сприяти виявленню зон актуального i найближчого розвитку, з урахуванням специфіки фізичного і психічного розвитку $[5,28]$.

Розглянемо поняття "готовність соціального педагога до реалізації інклюзивної освіти”. Л. Міщик трактує готовність соціального педагога до реалізації інклюзії як цілісне, особистісне утворення, що включає професійні, моральні, соціальні, психологічні властивості особистості, що забезпечують результативність діяльності. Як компоненти виділяють професійну і психологічну готовність до реалізації інклюзивної освіти $[7,11]$.

С. Сорокоумова в структурі готовності соціального педагога до реалізації інклюзивної освіти виокремлює наступні компоненти: особистісна готовність, ціннісно-смислова та професійна готовність [9, 72]. Дослідниця акцентує увагу на позитивній мотивації соціального педагога до реалізації освіти як основи особистісної готовності соціального педагога до інклюзії, виокремлює професійну і особистісну готовність соціального педагога.

Структура професійно-особистісної готовності являє собою єдність двох блоків: особистісного та професійного. Особистісний блок утворений індивідуальними та ціннісними орієнтаціями, очікування та мотивація суб'єкта, Я-концепція. Професійний блок утворений змістовними i статусними характеристиками професійної діяльності. У ньому можна виділити зовнішній і внутрішній аспекти [8, 317]. Професійний i особистісний блоки знаходяться в тісному взаємозв'язку і безперервній взаємодії.

Високий професіоналізм майбутніх соціальних педагогів залежить не тільки від наявності професійних компетенцій, здобутих у навчанні та необхідних для роботи, а й певних особистісних 
якостей (емпатія, толерантність, педагогічний оптимізм, високий рівень самоконтроль та саморегуляції, доброзичливість, перцептивні вміння, креативність, творчий підхід до розв’язання проблем, завдань педагогічної роботи) $[3,13]$.

В основі професійно-особистісної готовності майбутнього соціального педагога до роботи в інклюзивному середовищі є позитивне емоційне відношенні, прагнення до професійного вдосконалення і саморозвитку професійно значущих якостей. 3 позиції компетентнісного підходу, готовність майбутнього соціального педагога до реалізації професійної діяльності в інклюзивному середовищі розглядаємо як інтегральне особистісне утворення, що включає мотиваційно-ціннісний, операційно-діяльнісний, рефлексивно-оцінний компоненти $[10,52]$.

3 метою гармонізації та розвитку структурних компонентів професійно-особистісної готовності майбутнього соціального педагога до роботи в інклюзивному середовищі науковці пропонують використання таких методів роботи: занурення в діяльність з розв'язання проблемних професійного завдання, цілепокладання, планування i конструювання освітнього процесу, проєктування корекційно-розвивального середовища, розробка програм самоосвіти, інтерактивні, дискусійні, імітаційні методи. Необхідно включати в роботу 3 педагогами технології проєктування індивідуального корекційно-освітнього маршруту, групової роботи, розвитку критичного мислення, технології навчання методом кейсів $[11,19]$.

Ефективність тренінгових технологій для підготовки майбутніх соціальних педагогів до роботи в інклюзивному середовищі зумовлена переосмислення особливостей професії i професійно-особистісного потенціалу, можливостей самореалізації в роботі з різними категоріями дітей, а також осмислення перспектив розвитку в професійної діяльності [2, 29].

Використання тренінгових технологій має на меті посилити якість підготовки майбутніх соціальних педагогів до роботи в інклюзивному середовищі. 22-25 травня 2018 р. кафедра соціальної педагогіки та корекційної освіти Дрогобицького державного педагогічного університету імені Івана Франка організувала Міжнародний тиждень науки “Соціальна інклюзія: виклики сьогодення”. У заході взяли участь представники зарубіжних закладів вищої освіти і соціальних служб Бельгії, Нідерландів, Данії, Румунії.

Протягом міжнародного тижня відбувся семінар: “Інклюзивна освіта: 6 ключів до майбутнього". Під керівництвом викладачів Елс Калленс (університет прикладних наук ВIBEC, Бельгія), Алі Віт і Яна Ховінга (університет прикладних наук м. Гронінген, Нідерланди) були обговорені актуальні питання організації інклюзивної освіти в Бельгії, Нідерландах, Україні. Проаналізовано та апробовано на практиці ключі: “Розуміння та роль інклюзії”, “Рефлексія", “Комунікація”, “Співпраця”, “Цілісний погляд на дитину”, “Адаптація”, здійснено огляд досвіду інклюзивного навчання у країнах Свропейського Союзу.

Студенти та викладачі обговорили проблеми інклюзивної освіти в ранньому дитинстві за участю представників дошкільних закладів, загальноосвітніх шкіл, спеціалізованих освітніх закладів Дрогобича, Трускавця, Самбора, Дрогобицького і Самбірського районів.

Традиційно в координатах впровадження міжнародного досвіду у підготовку майбутніх соціальних педагогів на факультеті психології, педагогіки та соціальної роботи відбуваються численні Міжнародні україно-румуно-бельгійські науково-методичні семінари-тренінги “Соціальнопедагогічна та корекційна робота 3 дітьми 3 особливими потребами" (11-15 листопада 2013 р.), “Технології соціально-педагогічної роботи з дітьми з особливими потребами" (12-16 травня, 2014 р.), "Корекційна та соціально-педагогічна робота 3 людьми 3 особливими потребами” (03-07 листопада 2014 р.), “Розвиток соціальних навичок у соціально-педагогічній роботі 3 дітьми та молоддю з особливими потребами" (16-20 листопада, 2015 р.), “Соціально-педагогічний супровід сімей з дітьми з особливими потребами” (26-29 квітня, 2016 р.), “Технології соціальної роботи в реабілітаційних центрах" (26-29 вересня, 2016 р.), “Соціально-педагогічна робота з дітьми 3 особливими потребами та їх родинами” (2-5 травня, 2017 р.), “Інноваційні технології соціальнопедагогічної підтримки дітей $з$ особливими потребами” (30 жовтня-04 листопада 2017 р.), “Формування соціальних навичок у дітей 3 особливими потребами” (26-30 листопада 2018 р.), “Сучасні технології соціальнопедагогічного супроводу дітей та молоді 3 особливими потребами в умовах інклюзивної освіти" (25-29 березня 2019 р.).

Тренінги проводять багаторічні партнери факультету - спеціалісти соціального центру для людей з обмеженими можливостями “Зевенберген” та інклюзивного центру “Крістал” (Румунія). Робота зазвичай відбувається у групах “Соціальні навички як напрям командної роботи”, “Розуміння аутизму” "Базові навички у роботі 3 


\section{ПРОФЕСІЙНА ГОТОВНІСТЬ МАЙБУТНІХ СОЦАЛЬНИХ ПЕДАГОГІВ ДО РОБОТИ В ІНКЛЮЗИВНОМУ СЕРЕДОВИЩІ}

дітьми $з$ особливими потребами в умовах інклюзивного-освітнього середовища”. Учасники серії тренінгових занять мають змогу ознайомитися з цікавим досвідом практичної роботи з дітьми з особливими потребами в умовах інклюзивної освіти, відпрацьовувати сучасні технології соціально-педагогічного супроводу дітей з особливими потребами у закладах загальної середньої освіти, удосконалювали майбутні вміння і навички підтримки цієї категорії дітей.

Уміле керівництво тренінгом забезпечує максимальний ефект та створення умов для формування нового значущого досвіду соціальної поведінки майбутнього соціального педагога. Тренер сприяє розвитку пізнавального інтересу до професійної діяльності і формує у студентів готовність до продуктивного професійного життя $[6,53]$.

Ефективна тренінгова діяльність відбувається 3 урахуванням та аналізом особливостей навчально-виховного процесу та вікових особливостей дітей $з$ особливими освітніми потребами. Наведемо змістове наповнення тренінгів:

- виявлення проблемних соціальних та корекційних ситуацій. Найбільш часто зустрічаються проблеми, пов'язані з шкільним фактором і структурою організації класу;

- розвиток системи комунікації серед учасників команди. Більшість завдань тренінгу складні та дитиноцентровані. У кожної тренінгової групи виявляється свій підхід до їх виконання: хтось вирішує одразу ж, хтось виробляє план, але стає зрозумілим одне - якщо вони не будуть ефективно взаємодіяти, їх спіткає невдача, тому необхідно оволодіти навичками компетентного спілкування;

- формування навичок індивідуальної та групової рефлексії. В процесі тренінгу після кожної вправи тренери пропонують учасникам обговорити, що трапилося: “що їм вдалося зробити добре, що гірше, що б вони зробили поіншому";

- створення позитивного соціального оточення. Для цього під час тренінгу акумулюються емоції, психологічні особливості та якості особистості. Крім цього, учасники тренінгу вчаться розпізнавати емоції дітей 3 особливими потребами.

Висновки. Однією з умов успішної реалізації інклюзивної освіти $є$ професійна готовність майбутніх соціальних педагогів до роботи з дітьми 3 особливими освітніми потребами. Отже, професійну готовність майбутнього соціального педагога до інклюзії визначають рівень знань і компетенцій, здобутих в умовах закладів вищої освіти, що дозволяють ефективно здійснювати соціально-педагогічну діяльність. Готовність майбутніх соціальних педагогів до роботи в сфері освітньої інклюзії повинна відповідають сучасним запитам суспільства. Нами встановлено, що професійна діяльність в умовах інклюзії $є$ динамічною, що вимагає від фахівця постійного вдосконалення і пошуку нових шляхів розв'язання соціально-педагогічних завдань.

Вважаємо, що важливим у забезпеченні готовності майбутніх соціальних педагогів до професійної діяльності в умовах інклюзивного середовища забезпечить використання у їх підготовці комплексу тренінгових занять, лекцій та майстер-класів. Такий підхід надасть змогу створити нові взірці інклюзивної практики, сформувати уміння проєктувати індивідуальну траєкторію розвитку кожної дитини з особливими освітніми потребами та створювати концепцію розвитку як дитячої групи (класу), так і окремої дитини.

\section{ЛІТЕРАТУРА}

1. Бондар В. І. Інклюзивне навчання та підготовка педагогічних кадрів для його реалізації. Науковий часопис НПУ імені М. П. Драгоманова. Серія 19. Корекційна педагогіка та психологія. Вип.15. 2010. С.39-42.

2. Васягина Н. Н., Марчук Н. Ю. Оптимизация профессионально-личностной направленности педагога. Учеб.-метод. пособие. Екатеринбург, $2013.145 \mathrm{c}$.

3. Зязюн I. А. Актуальні проблеми професійнопедагогічної підготовки вчителя. Київ : Либідь, $2002.40 \mathrm{c}$.

4.Ивенских И.В., Сорокоумова С.Н. Профилизация будущих педагогов начальной школы для системы инклюзивного образования. Проблемы современного педагогического образования. 2017. №56. C. 367-373.

5. Ілляшенко Т. Інтеграція дітей з особливими освітніми потребами у загальноосвітній заклад. Соціальний педагог. 2009. № 5. С.26-35.

6. Колупаєва А. Інклюзивна освіта в контексті реалій сьогодення. Практика управління закладом освіти. 2010. № 4. С.52-56.

7. Мищик Л.И. Профессиональная подготовка соччильного педагога (педагогический, психологический и управленческий аспекты). Запорожье : ИПК “Запоріжжя”. 1996. 104 с.

8. Сластенин В. А. Социальная педагогіка и социальная работа : личность и професия. Теория и практика сочиальной работы : отечественный 


\section{ПРОФЕСІЙНА ГОТОВНІСТЬ МАЙБУТНІХ СОЦІАЛЬНИХ ПЕДАГОГІВ ДО РОБОТИ В ІНКЛЮЗИВНОМУ СЕРЕДОВИЩІ}

и зарубежный опит. Москва: 1993. Т. 1-2. С. $316-323$.

9. Сорокоумова С. Н. Инклюзивное образование. Москва: Московский государственный гуманитарный университет им. М. А. Шолохова, 2015. 203 с.

10. Харченко С. Я. Соціалізація дітей та молоді в прочесі сочіально-педагогічної діяльності: теорія і практика: монографія. Луганськ : Альма-матер. 2006. 320 с.

11. Vislie L. From integration to inclusion: focusing global trends and changes in the western European societies. European Journal of Special Needs Education. 2003. 18(1). C. 17-35.

\section{REFERENCES}

1. Bondar, V. I. (2010). Inkliuzyvne navchannia ta pidhotovka pedahohichnykh kadriv dlia yoho realizatsii [Inclusive education and training of teachers for its implementation]. Scientific journal of Drahomanov NATIONAL Pedagogical University. Correctional pedagogy and psychology. Edition 15. 2010. pp. 39-42. [in Ukrainian].

2. Vasiahyna, N. N. \& Marchuk, N. Yu. (2013). Optymyzatsyia professyonalno-lychnostnoi napravlennosty pedahoha [Optimization of the professional and personal orientation of the teacher]. Training and methodical book. Ekaterynburg, 145 p. [in Russian].

3. Ziaziun, I. A. (2002). Aktualni problemy profesiino-pedahohichnoi pidhotovky vchytelia [Actual problems of the teacher's professional and pedagogical training]. Kyiv: Lybid. 40 p. [in Ukrainian].

4. Yvenskykh, Y. V. \& Sorokoumova, S. N. (2017). Profylyzatsyia budushchykh pedahohov nachalnoi shkoly dlia systemy ynkliuzyvnoho obrazovanyia [Profiling of future primary school teachers for the system of inclusive education]. Problems of modern teacher education. No. 56. pp. 367-373. [in Russian].

5. Illiashenko, T. (2009). Intehratsiia ditei $z$ osoblyvymy osvitnimy potrebamy u zahalnoosvitnyoumy zakladi [Integration of children with special educational needs at the seconadary educational institution]. Social pedagogue. No. 5. pp. 26-35. [in Ukrainian].

6. Kolupaieva, A. (2010). Inkliuzyvna osvita v konteksti realii sohodennia [Inclusive coverage in the context of real life]. The practice of managing the mortgage of education. No. 4. pp. 52-56. [in Ukrainian].

7. Myshchyk L.Y. (1996). Professyonalnaia podhotovka sotsyalnoho pedahoha (pedahohycheskyi, psykholohycheskyi $i$ upravlencheskyi aspekty [Professional training of a social teacher (pedagogical, psychological and managerial aspects]. Zaporizhzhia, 104 p. [in Russian].

8. Slastenyn, V.A. (1993). Sotsyalnaia pedahohika y sotsyalnaia rabota : lychnost y profesyia [Social pedagogy and social work: personality and profession]. Theory and practice of social work: domestic and foreign experience. Moscov. Vol. 12. pp. 316-323. [in Russian].

9. Sorokoumova, S. N. (2015). Ynkliuzyvnoe obrazovanye [Inclusive education]. Moscow, 203 p. [in Russian].

10. Kharchenko, S. Ya. (2006). Sotsializatsiia ditei ta molodi $v$ protsesi sotsialno-pedahohichnoi diialnosti: teoriia $i$ praktyka [Socialization of children and young people in the process of social and pedagogical activity: theory and practice]. Luhansk, 320 p. [in Ukrainian].

11. Vislie, L. (2003). From integration to inclusion: focusing global trends and changes in the western European societies. European Journal of Special Needs Education. 18 (1). pp. 17-35. [in English].

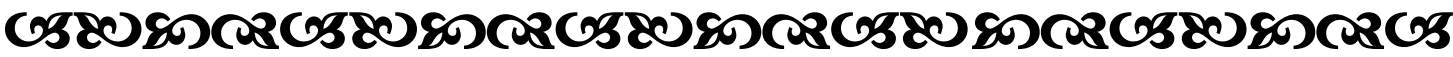

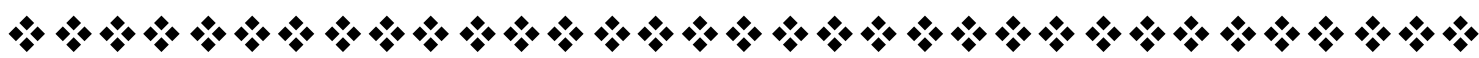

"У иентрі етичного Я вчителя стоїть його ставлення до знань, розумової праці, науки, освіченості, читання, книжки. В образі свого вихователя діти повинні Бачити безмежну відданість розумовому життю, науиі. Dітей сқоряє зақоханість учителя в знання. Якщо ви хочете, щоб вас шанували, будьте провідником дітей на стежиі подиву, зачудування істиною, яқу ви відқриваєте разом з дітьми, а дітям здається, цо відқривачі-вони, ви тільқи їх помічник, без яқого вони не можуть обійтися. Найтонше діти пізнають вашу прачю тоді, қоли з вашою допомогою вони мислять, відқривають істину, зачудовуються і дивуються".

Василь Сухомлинський уқраїнський педагог

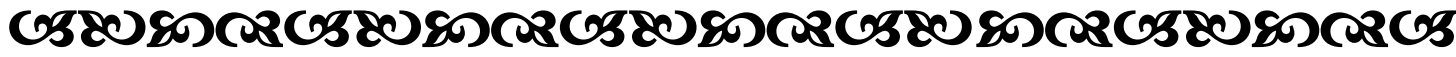

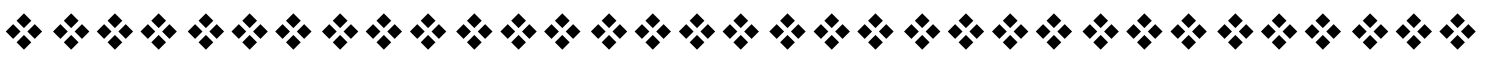

Молодь і ринок №2 (181), 2020 